\title{
Cellular localization of a vasoactive intestinal peptide in the mammalian and avian gastrointestinal tract
}

\author{
JUliA M. POLAK, A. G. E. PEARSE, J-C. GARAUD, AND S. R. BLOOM \\ From the Department of Histochemistry, Royal Postgraduate Medical School, Hammersmith Hospital, \\ London, and the Institute of Clinical Research, Middlesex Hospital, London
}

SUMMARY Immunohistochemical studies using an antiserum to a pure porcine vasoactive intestinal peptide, possessing no cross reactivity against the related hormones glucagon, secretin, and gastrininhibitory peptide, revealed a wide distribution of vasoactive intestinal peptide cells throughout the entire length of the mammalian and avian gut. The highest numbers of cells were present in the small intestine and more particularly in the large intestine in all species investigated.

Three types of endocrine cell in the mammalian gut are sufficiently widely distributed to be considered as the sites for production of vasoactive intestinal peptide. In the avian gut there are only two identifiable cell types.

Sequential immunofluorescence and silver staining showed, in the bird, that the enterochromaffin (EC) cell was not responsible. This procedure could not be used in our mammalian gut samples but here serial section immunofluorescence for enteroglucagon and vasoactive intestinal peptide indicated that the two cells were not identical and that each was differently localized in the mucosa.

These results leave the $\mathrm{D}$ cell of the Wiesbaden classification as the most likely site for the production of vasoactive intestinal peptide. The final identification must come from successful immune electron cytochemistry but this has not yet been achieved.

A polypeptide having strong vascular effects was isolated by Said and Mutt (1970) from porcine intestine. Named the vasoactive intestinal peptide (VIP), it was subsequently purified (Said and Mutt, 1972) and finally its amino acid sequence was determined by Mutt (quoted by Bodansky, Klausner, and Said, 1973). The biological actions of this 28-residue peptide, which shares a number of amino acid sequences with glucagon, secretin, and gastrin-inhibitory peptide (GIP), include vasodilatation, lowered blood pressure, increased cardiac output, glycogenolysis, and relaxation of smooth muscle (Said and Mutt, 1970; Piper, Said, and Vane, 1970). Other important actions have been described: in the cat, for instance, VIP has a secretin-like activity on the exocrine pancreas (Said and Mutt, 1972) and it has been shown by Barbezat and Grossman (1971) to stimulate small intestinal juice flow and to inhibit histamine-stimulated gastric acid secretion. Recently (Nilsson, 1973) VIP has been isolated from chicken intestine but its constitution has not yet been determined.

Received for publication 22 May 1974.
Six of the known gastrointestinal peptides have established amino acid sequences (gastrin, GIP, VIP, secretin, cholecystokinin-pancreozymin, and motilin). For three of these the cellular localization has been determined. These are gastrin (McGuigan, 1968; Pearse and Bussolati, 1970; Bussolati and Pearse, 1970), secretin (Bussolati, Capella, Solcia, Vassallo, and Vezzadini, 1971; Polak, Bloom, Coulling, and Pearse, 1971a), and GIP (Polak, Bloom, Kuzio, Brown, and Pearse, 1973). Using antipancreatic glucagon serum, which cross reacts with enteroglucagon, Polak et al (1971b) found that this fourth hormone was produced by the $L$ (now called EG) cells of the intestine and the A (now A-like) cells of the fundus of the stomach.

In this paper we report a series of immunofluorescence-based studies on the localization of VIP in the mammalian and avian gastrointestinal mucosa.

\section{Materials and Methods}

From the mammalian gut samples of mucosa were 
taken, as soon as possible after killing, from fundus, antrum, duodenum (divided into three portions), jejunum, ileum, and colon (divided into two portions). From avian gut samples were taken from the proventriculus, gizzard, duodenum (first and second parts), small intestine (first and second parts), large intestine, caecum, and colon. Small pieces from each of these regions were processed in a number of different ways for various procedures.

We used two mongrel dogs (3-6 months old), one pig, one baboon, and 30 Japanese quails. The pig received a dose of atropine $(3 \mathrm{ml} 1 \mathrm{M}$ intramuscularly) 14 hours before sacrifice. Some of the quails were given $600-700 \mu \mathrm{g} / \mathrm{kg}$ atropine in sterile saline intraperitoneally four hours before sacrifice.

\section{Immunohistochemistry}

Three fixation schedules were used: (1) methanolfree formaldehyde, paraffin embedding (Polak, Bussolati, and Pearse, 1971): (2) $10 \%$ carbodiimide, cryostat sections (Kendall, Polak, and Pearse, 1971); (3) freeze-drying and diethylpyrocarbonate (DEPC) vapour fixation $\left(55^{\circ} \mathrm{C}, 3\right.$ hours), with subsequent paraffin embedding (Pearse, Polak, Adams, and Kendall, 1974).

For immunofluorescence we used an indirect (sandwich) technique with rabbit anti-VIP serum as the first layer and fluorescein (FITC)-labelled goat antirabbit IgG serum (Hyland) as the second layer. For the peroxidase method we prepared labelled donkey antirabbit IgG and rabbit antiguinea-pig IgG attaching the enzyme (peroxidase type VI, Sigma) to the globulin by the glutaraldehyde method (Avrameas and Ternynck, 1971). Peroxidase activity in sections was demonstrated by the method of Graham and Karnovsky (1966).

Because in our earliest preparations the level of VIP fluorescence in individual cells was lower than expected, and because of the known lability of VIP to peptidases, we added the peptidase inhibitor trasylol (in equal parts) to the first layer serum. Thereafter VIP fluorescence levels were comparable with those obtained with more stable hormones.

In both immunofluorescence and immunoperoxidase procedures we used as controls (1) normal rabbit serum as the first layer, (2) second layer alone, (3) first layer antiserum absorbed with pure VIP.

\section{PREPARATION OF ANTISERA}

Pure porcine VIP was coupled to guinea-pig serum albumin with 1-ethyl-3 (3-dimethylaminopropyl) carbodiimide hydrochloride (CDI) according to the technique of Goodfriend, Levine, and Fasman (1964). Injections were given to rabbits at regular intervals and sera were harvested after several months. Control rabbits received injections of CDItreated albumin.

The specificity of an antiserum was tested by measuring the displacement of labelled VIP from the antiserum by unrelated antigen and also by measuring its ability to bind other radioactive antisera. No cross reactivity was observed with glucagon, secretin, or gastrin-inhibitory peptide.

\section{FLUORESCENCE MICROSCOPY}

This was carried out using a Zeiss (Oberkochen) standard universal microscope with an HBO 200 lamp, BG12 and BG38 excitation filters, and a K530 barrier filter $(50 \%$ transmission at about $530 \mathrm{~nm})$, and also a Leitz Orthoplan microscope with HBO 100 and XBO 75 lamps and a Ploem illuminator. The fluorescein label was excited at $490 \mathrm{~nm}$ using two KP 490 interference filters and a TK 510 dichroic mirror. For examination a K 515 barrier filter was used and photomicrographs were taken on Ilford FP4 film.

\section{LIGHT MICROSCOPY AND CYTOCHEMISTRY}

A battery of methods was employed as described by Polak et al (1973).

\section{ELECTRON MICROSCOPY}

This was carried out as described by Polak et al (1973). Sections were viewed in AEI 6B and Corinth 275 microscopes.

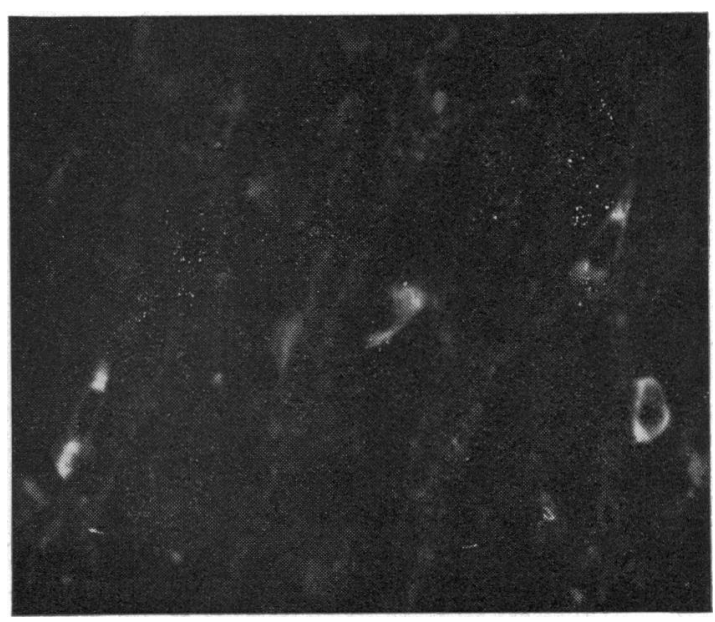

Fig 1 Lower ileum, dog. Freeze-dried, DEPC vapourfixed section. Indirect immunofluorescence with trasylol protection. A number of VIP-reacting cells are seen, one of which has an apical process extending to the lumen. $\times 600$ 


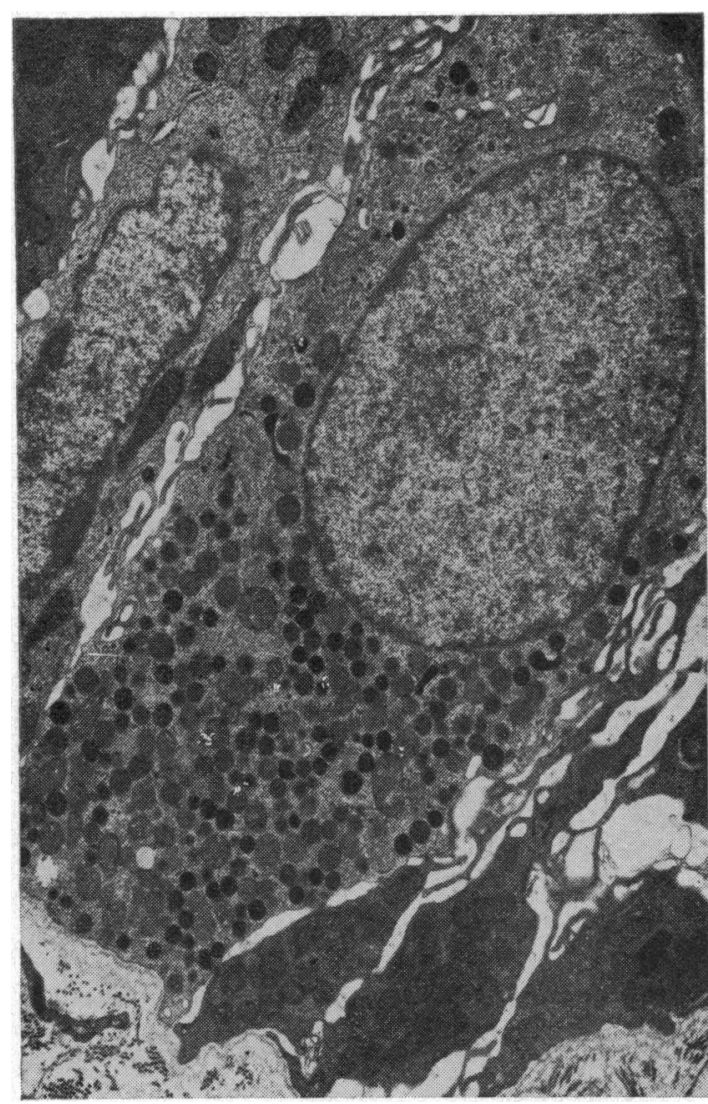

Fig 2 Human duodenum. Glutaraldehyde-osmium-fixed preparation, counterstained with uranyl acetate and lead citrate. This D cell shows the characteristic mixed population of secretory granules stored in the basal half of the cell. $\times 10000$

\section{Results}

In the mammalian gastrointestinal tract we obtained satisfactory results only in DEPC preparations incubated in the presence of trasylol. The distribution of cells reacting with anti-VIP sera was found to be extremely wide. They were present in all regions examined but in highest numbers in the large intestine of all three species and also in the body of the stomach in both pig and baboon. No fluorescence was observed in any endocrine cell in the control sections. In most cases the VIP cells were pyramidal, or occasionally oval, and often a long apical process could be seen extending towards the lumen of a gland. These appearances are shown in figure 1.

We were able to identify, in our EM samples, all the endocrine cells of the modified Wiesbaden classi- fications (Solcia, Pearse, Grube, Kobayashi, Bussolati, Creutzfeldt, and Gepts, 1973). The only cells in this classification which have a general distribution throughout the entire gastrointestinal tract are (1) enterochromaffin (EC) cells, (2) EG cells, and (3) D cells (fig 2). The storage granules of this last variety can be seen from the illustration to be exact counterparts of those of the pancreatic D cell. All the other cell types (G, ECL, A-like, $D_{1}, S, E G$, and I) are restricted so far as our preliminary observations go, to more or less precise regions of the gut.

Mammalian VIP cells were observed to stain weakly with lead haematoxylin and they gave a negative reaction with the DMAB method for tryptophan. It was not found possible to carry out sequentially either of the silver stains for argentaffinity or argyrophilia on DEPC-fixed material.

When serial $4 \mu \mathrm{m}$ sections were incubated for enteroglucagon and VIP respectively we found that there was virtually no identity between the two cell types, and, furthermore, the zonal distributions of the EG cell and the VIP cell in the mucosa were completely different (figs $3 a$ and $3 b$ ).

In the avian gastrointestinal tract we obtained good results with all three preparative techniques although the DEPC preparations were always superior. Vasoactive intestinal peptide cells were present in all regions except the gizzard. Only two endocrine cell types can confidently be distinguished by electron microscopy in the avian intestine, and were clearly to be correlated with the argentaffin and argyrophil varieties on light microscopy. The VIP cells were found both in the villi and in the crypt and neck regions of the glands. When present in the villi they tended to have an elongated or spindlelike form. When localized in the more basal regions of the mucosa they were more usually rounded (fig 4). Sequential immunofluorescence and silver staining, carried out on MFF-fixed material, showed that all the VIP cells in the avian gastrointestinal tract belonged to the argyrophil variety.

\section{Discussion}

Although VIP has not been established unequivocally as a hormone, several observations throw light on its possible physiological roles (Barbezat and Grossman, 1971; Said and Mutt, 1972; Dockray, 1973). Its association with a proportion of cases of the WDHA syndrome (pancreatic cholera), as described by Bloom, Polak, and Pearse (1973), supports the claim of VIP to true hormonal status. Fujita and Kobayashi (1971) have shown that instillation of $\mathrm{HCl}$ into the intestine results in a discharge of the granules of the D cell, identified ultrastructurally. This observation fits one of the possible physio- 


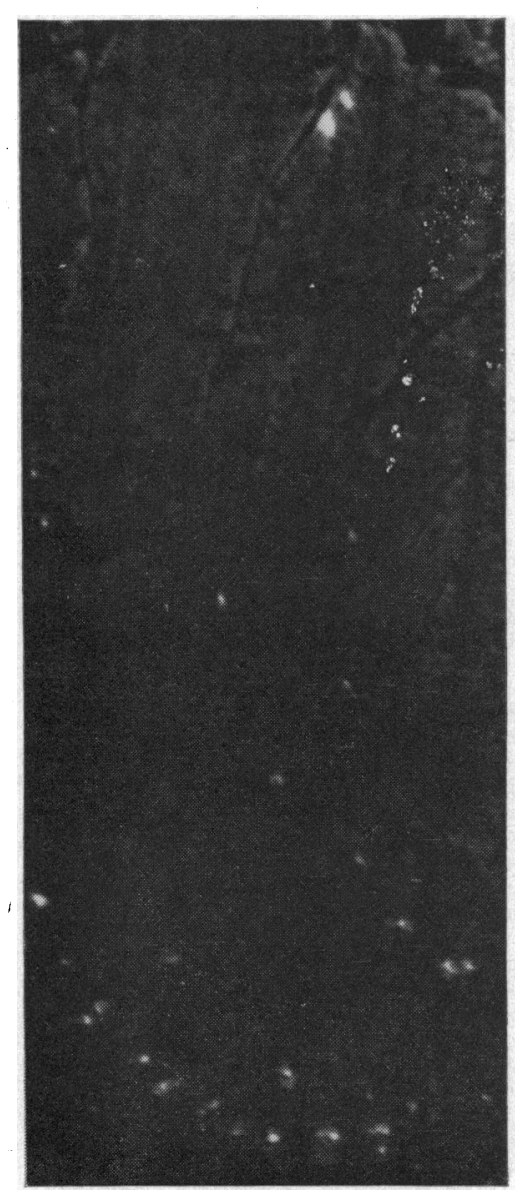

Fig 3a

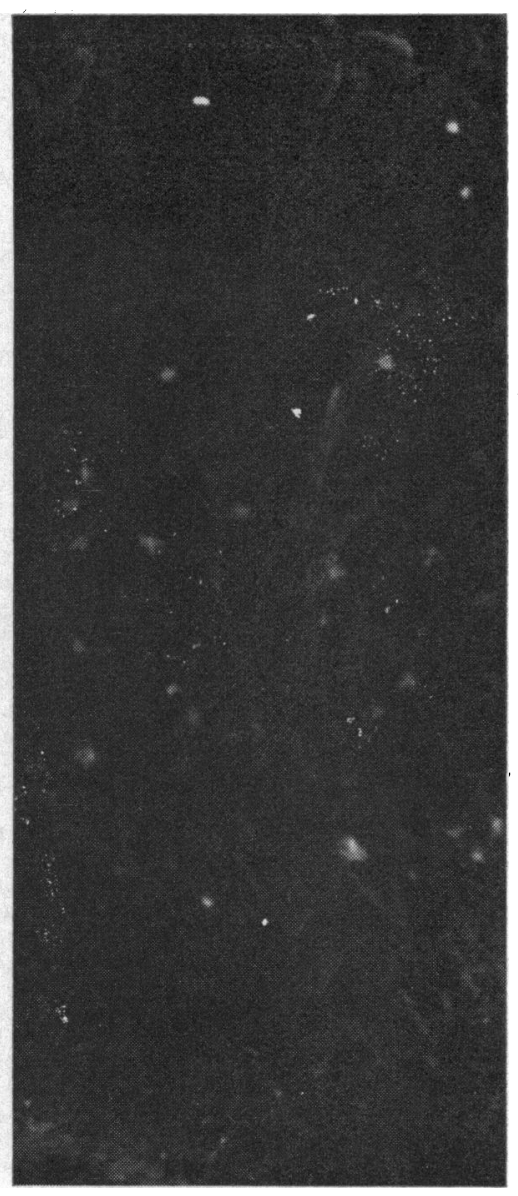

Figs 3a and 3b Lower ileum, dog. Serial freezedried, DEPC vapour-fixed sections. Indirect immunofluorescence for enteroglucagon (3a) and VIP (3b). The predominantly basal distribution of $E G$ cells should be compared with the diffuse mid-zonal distribution of the VIP cells. $\times 270$

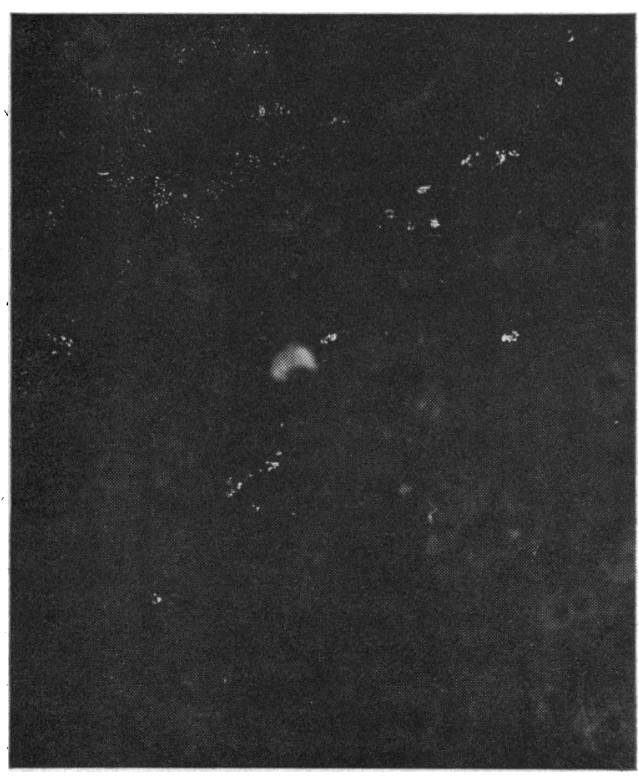

Fig 3b

Fig 4 Lower jejunum, quail. Freeze-dried, DEPC vapour-fixed section. Indirect immunofluorescence (without trasylol). A single round or oval VIP cell in the basal region of the mucosa. $\times 500$ 
logical roles for VIP, in relation to inhibition of gastric acid secretion.

Our results in the case of the mammalian gastrointestinal tract unfortunately do not allow us to identify completely the production of VIP with the $D$ cell. We have established that, of the three possible candidates (EC, EG, D), the enteroglucagon cell can probably be excluded. Our finding that the avian VIP cell is not the argentaffin EC cell can perhaps be extrapolated to mammalian gut but we cannot be completely certain that no mammalian EC cell contains vasoactive intestinal peptide.

The lability of mammalian VIP to preparative techniques means that it is at present demonstrable only by the technique of freeze drying followed by DEPC vapour. This precludes its identification at the EM level since cytological detail is inadequately retained. Successful identification of VIP with a single endocrine cell of the Wiesbaden classification thereforeawaits the discovery of a suitable preparative technique which will allow the peptide to be demonstrated immunologically in resin-embedded semithin sections.

We thank Professor V. Mutt and Dr S. I. Said for supplying pure VIP for immunization. The work was carried out with the assistance of grants from the Wellcome Trust and the Medical Research Council. We also acknowledge the technical assistance of Mrs Caroline Adams.

\section{References}

Avrameas, S., and Ternynck, T. (1971). Peroxidase labelled antibody and $\mathrm{Fab}$ conjugates with enhanced intracellular penetration. Immunochemistry, 8, 1175-1179.

Barbezat, G. O., and Grossman, M. I. (1971). Intestinal secretion: stimulation by peptides. Science, 174, 422-424.

Bloom, S. R., Polak, J. M., and Pearse, A. G. E. (1973). Vasoactive intestinal peptide and watery-diarrhoea syndrome. Lancet, 2 , 14-16.

Bodanszky, M., Klausner, Y. S., and Said, S. I. (1973). Biological activities of synthetic peptides corresponding to fragments and to the entire sequence of the vasoactive intestinal peptide (VIP). Proc. nat. Acad. Sci. (Wash.), 70, 382-384.
Bussolati, G., Capella, C., Solcia, E., Vassallo, G., and Vezzadini, P. (1971). Ultrastructural and immunofluorescent investigations on the secretin cell in the dog intestinal mucosa. Histochemie, 26, 218-227.

Bussolati, G., and Pearse, A. G. E. (1970). Immunofluorescent localization of the gastrin-secreting $\mathbf{G}$ cells in the pyloric antrum of the pig. Histochemie, 21, 1-4.

Dockray, G. J. (1973). Vasoactive intestinal peptide: secretin-like action on the avian pancreas. Experientia (Basel), 29, 15101511.

Fujita, T., and Kobayashi, S. (1971). Experimentally induced granule release in the endocrine cells of dog pyloric antrum. Z. Zellforsch., 116, 52-60.

Goodfriend, T. L., Levine, L., and Fasman, G. D. (1964). Antibodies to bradykinin and angiotensin: a use of carbodiimides in immunology. Science, 144, 1344-1346.

Graham, R. C., and Karnovsky, M. J. (1966). The early stages of absorption of injected horseradish peroxidase in the proximal tubules of mouse kidney: ultrastructural cytochemistry by a new technique. J. Histochem. Cytochem., 14, 291-302.

Kendall, P. A., Polak, J. M., and Pearse, A. G. E. (1971). Carbodiimide fixation for immunohistochemistry: observations on fixation of polypeptide hormones. Experientia (Basel) 27, 1104-1106.

McGuigan, J. E. (1968). Gastric mucosal intracellular localization of gastrin by immunofluorescence. Gastroenterology, 55, 315-327.

Nilsson, A. (1973). Unpublished data.

Pearse, A. G. E., and Bussolati, G. (1970). Immunofluorescence studies of the distribution of gastrin cells in different clinical states. Gut, 11, 646-648.

Pearse, A. G. E., Polak, J. M., Adams, C., and Kendall, P. A. (1974). Diethylpyrocarbonate, a vapour phase fixative for immunofluorescence studies on polypeptide hormones. Histochem. J. 6, 347-352.

Piper, P. J., Said, S. I., and Vane, J. R. (1970). Effects on smooth muscle preparations of unidentified vasoactive peptides from intestine and lung. Nature (Lond.), 225, 1144-1146.

Polak, J. M., Bloom, S. R., Coulling, I., and Pearse, A. G. E. (1971a). Immunofluorescent localization of secretin in the canine duodenum. Gut, 12, 605-610.

Polak, J. M., Bloom, S. R., Coulling, I., and Pearse, A. G. E. (1971b). Immunofluorescent localization of enteroglucagon cells in the gastrointestinal tract of the dog. Gut, 12, 311-318.

Polak, J. M., Bloom, S. R., Kuzio, M., Brown, J. C., and Pearse, A. G. E. (1973). Cellular localization of gastric inhibitory polypeptide in the duodenum and jejunum. Gut, 14, 284-288.

Polak, J. M., Bussolati, G., and Pearse, A. G. E. (1971). Cytochemical, immunofluorescence and ultrastructural investigations on the antral $\mathrm{G}$ cells in hyperparathyroidism. Virchows Arch. Abt. B. Zellpath., 9, 187-197.

Said, S. I., and Mutt, V. (1970). Polypeptide with broad biological activity: isolation from small intestine. Science, 169, 1217-1218.

Said, S. I., and Mutt, V. (1972). Isolation from porcine-intestinal wall of a vasoactive octacosapeptide related to secretin and glucagon. Europ. J. Biochem., 28, 190-204.

Solcia, E., Pearse, A. G. E., Grube, D., Kobayashi, S., Bussolati, G., Creutzfeldt, W., and Gepts, W. (1973). Revised Wiesbaden classification of gut cells. R.C. Gastroent., 5, 13-16. 